\title{
GURU SEBAGAI SEORANG PENDIDIK BANGSA
}

\section{Mei Sinta Susangko Putri, Ida Susanti}

Universitas Nahdlatul Ulama Sidoarjo

Email: meisinta699@gmail.com

\section{Pengertian dari seorang guru}

Guru merupakan orang tua kedua bagi anak didiknya ketika berada disekolah.Dalam bahasa jawa guru sendiri memiliki arti "di gugu lan di tiru"artinya guru adalah panutan bagi setiap peserta didiknya mulai dari perkataan hingga sikap dan tingkah lakunya. Guru merupakan faktor yang sangat dominan dan dan paling terpenting dalam pendidikan formal pada umumnya karena bagi siswa guru sering dijadikan tokoh teladan bahkan menjadi tokoh identitas diri(Wijaya dan Rusyan,1994).Guru merupakan jendela ilmu bagi anak bangsa dari berbagai pengetahuan dan ilmu yang telah dimiliki olehnya di tuangkan dan di ajarkan oleh peserta didiknya agar anak-anaknya memiliki pengetahuan dan dapat berpotensi ketika berada di zaman era globalisasi maka 
itu guru merupakan pahlawan tanpa tanda jasa.Guru tak hanya mengaplikasikan ilmunya ketika mengajar dikelas saja tetapi dimanapun dia berada dia harus mampu mengaplikasikannya seperti halnya ketika bersosialisasi di masyarakat. Guru merupakan seseorang yang multitalenta dari berbagai bidang mata pelajaran sama halnya dengan guru sekolah dasar dia mampu mengusai dari berbagai mata pelajaran sehingga dimanapun dia berada dia mampu mengondisikannya..

Menurut

Gunawan

(1996) mengemukakan bahwa guru merupakan perencana,pelaksana sekaligus sebagai evaluator pembelajaran dikelas, maka peserta didik merupakan subjek yang terlibat langsung dalam proses untuk mencapai tujuan pendidikan.Guru merupakan seseorang yang terpenting bagi peserta didiknya karena guru merupakan ujung tombak yang paling terpenting dalam sebuah pendidikan karena seorang guru sangat mempengaruhi, mendidik, dan mengembangkan peserta didiknya untuk menggapai sebuah cita-cita yang diharapkan oleh peserta didiknya.Oleh karena itu untuk meningkatkan mutu pendidikan yang lebih baik lagi seorang guru di tuntut untuk memiliki sebuah profesionalitas sebagai seorang guru dan memiliki kinerja yang mampu untuk mengolah sebuah 
pendidikan.Berkualitas atau tidaknya sebuah proses pendidikan tergantung dari pada kreativitas dan inovasi yang dimiliki oleh guru itu sendiri.Secara umum mutu pendidikan yang baik mampu menjadi sebuah tolak ukur bagi keberhasilan kinerja yang di tunjukkan oleh guru walaupun banyak factor factor yang menjadi penghalang bagi kinerja guru.Pendidikan adalah suatu kegiatan pembentukan kesadaran dan kepribadian anak didik di samping transfer ilmu dan keahlian(Qori'ah et al., 2017).

Tips mengelola institusi pendidikan adalah niat mendidik dan berjuang karena Allah ta'ala. Niscaya rintangan sebesar apapun akan terasa ringan dihadapan kita. Melihat anak mengenal Allah Ta'ala dan sukses akhlak dan pengetahuannya merupakan kebahagiaan pendidik (Yuniarti et al., 2017). Cari ilmu yang bermanfaat dan patuhi aturan-aturan yang ada. Bijaksana dan pantang menyerah dalam belajar adalah kunci kesuksesan. Pendidikan dan Akhlak yang baik melahirkan generasi yang baik juga (Nahdiyah et al., 2017). Hubungan pendidikan antara guru dan murid itu seperti aliran listrik dengan lampu. Bagaimana lampu itu bisa menyala kalau aliran listriknya juga mati ?. Bagaimana murid itu bisa berprestasi sedangkan guru sendiri tidak pernah berprestasi dan 
mendoakan.

menyampaikan ilmu dan mentransformasi orang lain menjadi lebih baik (Fidiana, et al., 2017).

\section{Faktor-Faktor yang mempengaruhi kinerja guru}

sangat terpenting bagi mutu pendidikan.Kinerja sendiri memiliki arti dimana seorang pendidik mampu menigkatkan keberhasilan selama mengajar sesui dengan standart yang telah di capai.Sulistyorini (2001) menjelaskan bahwa kinerja adalah tingkat keberhasilan seseorang atau kelompok orang dalam melaksanakan tugas dan tanggung jawabnya serta kemampuan untuk mencapai tujuan dan standart yang telah di tetapkan.Fatah (1996) menegaskan bahwa kinerja diartikan sebagai ungkapan kemajuan yang didasari oleh pengetahuan,sikap dan motivasi dalam menghasilkan suatu pekerjaan.Guru di anggap sebagai orang yang berperan penting dalam sebuah pendidik tapi dalam melaksanakan tugas dan kewajibannya sebagai guru tidak terlepas dari beberapa factor diantaranya faktor internal dan factor eksternal. Diantaranya yaitu: 
1. Kepribadian dan dedikasi

Setiap guru memiliki kepribadian yang sangat berbeda beda sebagai seorang yang mendidik anak muridnya karena kepribadian merupakan ciri khas yang dimiliki oleh seorang guru.Ciri khas tersebut yang membedakan antara guru yang satu dengan guru yang lainnya. Zakiah Darajat (dalam Djamarah SB,1994) bahwa kepribadian yang sesungguhnya dalah abstrak,sukar dilihat atau diketahui secara nyata yang dapat diketahui adalah penampilannya dalam segala segi dan aspek kehidupan, misalnya berupa ucapan,tindakan,caranya bergaul,berpakaian dan dalam menghadapi setiap persoalan.

2. Profesi Guru

Menurut Pidarta (1999) menyatakan bahwa profesi ialah suatu jabatan atau pekerjaan biasa seperti halnya dengan pekerjaan-pekerjaan lainnya.Tetapi pekerjaan itu harus diterapkan untuk masyarakat umum bukan untuk kepentingan individual, kelompok, ataupun golongan tertentu.

3. Kemampuan Mengajar

Sebagai seorang guru harus memiliki kemampuan mengajar jika tidak 
memiliki kemampuan mengajar maka akan menjadi kendala bagi sebuah proses pendidikan.Kemampuan mengajar sangat berperan penting karena kemampuan mengajar merupakan syarat yang harus dimiliki oleh seorang pendidik. Cooper (dalam Zahera, 1997) mengemukakan bahwa guru harus memiliki kemampuan merencanakan pengajaran, menuliskan tujuan pengajaran, menyajikan bahan ajar, memberikan pertanyaan kepada siswanya, mengajarkan konsep, berkomunikasi dengan siswa, mengamati kelas, dan mengevaluasi hasil belajar.

Pendidik tidak hanya kita jumpai di sekolah saja dimanapun kita dapat menjumpainya di sekolah,mapun lembaga pendidikan yang lainnya

\section{Beberapa orang yang terkait dalam Pendidikan}

Tujuan dalam sekolah tidaklah terlepas dari masyarakat dan lingkungannya begitu juga dengan sebaliknyaterjalinnya sebuah hubungan yang harmonis antara guru,sekolah dan orang tua akan membuka peluang bagi guru dalam mengkoordinasi dan mengawasi dalam proses belajar mengajar di sekolah dan 
keterlibatan bersama untuk memajukan peserta didik.Guru diharapkan dapat melakukan yang terbaik sesuai dengan keinginan orang tua yaitu tercapainya sebuah mutu pendidikan yang berkualitas. Hubungan yang baik dilengkapi dengan terjalinnya antara guru dan orang tua untuk membina serta rasa tanggung jawab bersama terhadap sebuah pendidikan.Hanya sebagian kecil waktu yang digunakan oleh guru dalam sekolahan terlebihnya sebagian besar bersama dengan orang tua yang mendidikinya ketika dirumah oleh karena itu guru merupakan orang tua kedua ketika berada di sekolah.Agar pendidikan berjalan dengan baik maka di perlukan adanya kerja sama antara guru dengan orang tua. Kewajiban seorang guru untuk menjalin sebuah komunikasi dengan wali murid merupakan bagian tugas guru dalam mendidik siswa dan mengembangkan pekerjaannya sebagai seorang guru.

Pendidik ialah orang yang bertanggung jawab terhadap pelaksanaan pendidikan dengan sasaran peserta didik.Peserta didik mengalami pendidikannya dalam tiga lingkungan yaitu lingkungan keluarga, lingkungan sekolah, dan lingkungan masyarakat.Sebab itu yang bertanggung jawab terhadap pendidikan yaitu orang tua, guru, pemimpin program pembelajaran, 
pelatihan, dan masyarakat/organisasi.Interaksi antara peserta didik dengan pendidik (interaksi edukatif).Interaksi edukatif pada dasarnya adalah komunikasi timbal balik antar peserta didik dengan pendidik yang terarah kepada tujuan pendidikan. Pencapaian tujuan pendidikan secara optimal ditempuh melalui proses berkomunikasi intensif dengan memanifulasikan isi, metode serta alat-alat pendidikan. Ke arah mana bimbingan ditujukan (tujuan pendidikan)

\section{Peran Guru Dalam Proses Belajar Mengajar}

(Noviana, 2015)Peranan guru dalam pendidikan sangatlah banyak proses belajar mengajar dan hasil belajar siswa sebagian besar ditentukan oleh peranan dan kompetensi guru.Guru yang baik akan mampu menciptakan lingkungan belajar yang efektif dan mampu mengelola kelas sehingga hasil belajar siswa berada pada tingkat yang optimal.

- Prey Katz yang menggambarkan peranan guru sebagai komunikator, sahabat yang dapat memberikan nasihat-nasihan, motivator sebagai pemberi inspirasi dan dorongan, pembimbing dalam pengembangan sikap dan tingkah laku serta nilai-nilai, 
dan sebagai orang yang menguasai bahan yang diajarkan.

- Havighurst menjelaskan bahwa peranan guru di sekolah sebagai pegawai dalam hubungan kedinasan, sebagai bawahan terhadap atasannya, sebagai kolega dalam hubungannya dengan teman sejawat, sebagai mediator dalam hubungannya dengan anak didik, sebagai pengatur disiplin, evaluator dan pengganti orang tua.

- James W. Brown mengemukakan bahwa tugas dan peranan guru antara lain menguasai dan mengembangkan materi pelajaran, merencanakan dan mempersiapkan pelajaran sehari-hari, mengontrol dan mengevaluasi kegiatan siswa.

- Federasi dan Organsasi Profesional Guru Sedunia mengungkapkan bahwa peranan guru di sekolah tidak hanya sebagai transmitter dari ide tetapi juga berperan sebagai transformer dan katalisator dari nilai dan sikap.

- Prey Katz yang menggambarkan peranan guru sebagai komunikator, sahabat yang dapat memberikan nasihat-nasihan, motivator sebagai pemberi inspirasi dan dorongan, pembimbing dalam pengembangan 
sikap dan tingkah laku serta nilai-nilai, dan sebagai orang yang menguasai bahan yang diajarkan.

- Havighurst menjelaskan bahwa peranan guru di sekolah sebagai pegawai dalam hubungan kedinasan, sebagai bawahan terhadap atasannya, sebagai kolega dalam hubungannya dengan teman sejawat, sebagai mediator dalam hubungannya dengan anak didik, sebagai pengatur disiplin, evaluator dan pengganti orang tua.

- James W. Brown mengemukakan bahwa tugas dan peranan guru antara lain menguasai dan mengembangkan materi pelajaran, merencanakan dan mempersiapkan pelajaran sehari-hari, mengontrol dan mengevaluasi kegiatan siswa.

- Federasi dan Organsasi Profesional Guru Sedunia mengungkapkan bahwa peranan guru di sekolah tidak hanya sebagai transmitter dari ide tetapi juga berperan sebagai transformer dan katalisator dari nilai dan sikap.

- Prey Katz yang menggambarkan peranan guru sebagai komunikator, sahabat yang dapat memberikan nasihat-nasihan, motivator sebagai pemberi inspirasi dan dorongan, 
pembimbing dalam pengembangan sikap dan tingkah laku serta nilai-nilai, dan sebagai orang yang menguasai bahan yang diajarkan.

- Havighurst menjelaskan bahwa peranan guru di sekolah sebagai pegawai dalam hubungan kedinasan, sebagai bawahan terhadap atasannya, sebagai kolega dalam hubungannya dengan teman sejawat, sebagai mediator dalam hubungannya dengan anak didik, sebagai pengatur disiplin, evaluator dan pengganti orang tua.

- James W. Brown mengemukakan bahwa tugas dan peranan guru antara lain menguasai dan mengembangkan materi pelajaran, merencanakan dan mempersiapkan pelajaran sehari-hari, mengontrol dan mengevaluasi kegiatan siswa.

- Federasi dan Organsasi Profesional Guru Sedunia mengungkapkan bahwa peranan guru di sekolah tidak hanya sebagai transmitter dari ide tetapi juga berperan sebagai transformer dan katalisator dari nilai dan sikap.

(Noviana, 2015)Mengatakan Berdasarkan pendapat-pendapat mengenai peranan guru diatas, Sardiman (2011: 144-146) merincikan 
peranan guru tersebut menjadi 9 peran guru. 9 peranan guru dalam kegiatan belajar mengajar tersebut yaitu:

1. Informator. Sebagai pelaksana mengajar informatif, laboratorium, studi lapangan dan sumber informasi kegiatan akademik maupun umum.

2. Organisator. Pengelola kegiatan akademik, silabus, workshop, jadwal pelajaran dan lain-lain. Organisasi komponen-komponen kegiatan belajar harus diatur oleh guru agar dapat mencapai efektivitas dan efisiensi dalam belajar pada diri guru maupun siswa.

3. Motivator.peran sebagai motivator penting artinya dalam rangka meningkatkan kegairahan dan pengembangan kegiatan belajar siswa. Guru harus mampu memberikan rangsangan, dorongan serta reinforcement untuk mengembangkan potensi siswa, menumbuhkan swadaya (aktivitas) dan daya cipta (kreativitas), sehingga akan terjadi dinamika dalam proses belajar.

4. Pengarah atau Director. Guru harus dapat membimbing dan mengarahkan 
kegiatan belajar siswa sesuai dengan tujuan yang dicita-citakan.

5. Inisiator. Guru sebagai pencetus ideide dalam proses belajar. Ide-ide yang dicetuskan hendaknya adalah ide-ide kreatif yang dapat dicontoh oleh anak didik.

6. Transmitter. Dalam kegiatan belajar mengajar guru juga akan bertindak selakuk penyebar kebijaksanaan pendidikan dan pengetahuan.

7. Fasilitator. Guru wajib memberikan fasilitas atau kemudahan dalam proses belajar mengajar misalnya dengan menciptakan susana kegiatan pembelajaran yang kondusif, seerasi dengan perkembangan siswa, sehingga interaksi belajar mengajar berlangsung efektif dan optimal.

8. Mediator. Mediator ini dapat diartikan sebagai penengah dalam kegiatan belajar siswa. Misalnya saja menengahi atau memberikan jalan keluar atau solusi ketika diskusi tidak berjalan dengan baik. Mediator juga dapat diartikan sebagai penyedia media pembelajaran.

9. Evaluator. Guru memiliki tugas untuk menilai dan mengamati perkembangan prestasi belajar peserta didik. Guru 
memiliki otoritas penuh dalam menilai peserta didik, namun demikian evaluasi tetap harus dilaksanakan dengan objektif. Evaluasi yang dilakukan guru harus dilakukan dengan metode dan prosedur tertentu yang telah direncanakan sebelum kegiatan pembelajaran dimulai.

\section{Guru SD}

Guru SD merupakan seorang yag memilki tugas mulia sebagai pendidik dan pengajar sekaligus sebagai pembentuk kepribadian siswa SD untuk mencetak generasi yang unggul, berwawasan dan berkepribadian baik (Maula et al., 2018).

\section{Presentase minat sebagai seorang guru}

(Achmad, 2015)Harapan guru honorer agar diangkat menjadi pegawai negeri sipil sebenarnya memiliki dua konsekuensi. Pertama, kesejahteraan memang akan meningkat. Kedua, mereka akan masuk ke dalam aturan main regulasi politik pendi1dikan yang muatannya banyak dibebani oleh tugastugas teknis (hard skill), dan di saat yang sama, pelan tapi pasti, bisa melumpuhkan 
kepedulian dan ketangguhan sebagai sosok pejuang pendidikan.

(Achmad, 2015) Mengatakan sebenarnya potensi para guru honorer dan guru tidak tetap yayasan cukup besar.Mereka adalah pejuang sunyi pendidikan.Berdasarkan data Direktorat Jenderal Guru dan Tenaga Kependidikan, total jumlah guru 3.015.315.Jumlah itu terdiri dari 2.294.191 guru PNS dan guru tetap yayasan (GTY).Sisanya, sebanyak 721.124 merupakan merupakan guru tidak tetap atau honorer K2.

(achmad, 2015) Mengatakan Tidak bermaksud mengecilkan semangat dan cita-cita guru, menjadi guru PNS sebenarnya tidak harus menjadi target akhir, selama pemerintah peduli terhadap kesejahteraan mereka.Bertahan menjadi guru honorer selama bertahun-tahun menunjukkan kualitas pengabdian yang tak diragukan lagi.Potensi idealisme itu seharusnya diapresiasi oleh pemerintah dengan pemberian gaji dan tunjangan yang setara dengan guru golongan manapun.

\section{Kesimpulan}

Guru merupakanorang tua kedua bagi anak didiknya ketika berada disekolah.Dalam 
bahasa jawa guru sendiri memiliki arti "di gugu lan di tiru"artinya guru adalah panutan bagi setiap peserta didiknya mulai dari perkataan hingga sikap dan tingkah lakunya

\section{Tugas-Tugas dari Seorang Guru}

1. Untuk melaksanakan sebuah tugas seorang guru memerlukan sebuah kemampuan atau kompetensi dalam pembelajaran salah satunya menyajikan bahan pelajaran berupa RPP.

2. Mampu menguasai kelas dengan baik

3. Mampu berinteraksi dengan peserta didik

4. Membuat sebuah peta konsep atau media yang menyenangkan untuk menarik daya anak untuk belajar

.Orang tua telah mempercayai bahwa sekolahan dan guru mampu mendidik dan membimbing anak anaknya,sekolah dasar merupakan sebuah lembaga sosial yang tidak dapat di pisahkan oleh mayarakat lingkungannya begitu juga sebaliknya.Guru merupakan lembaga formal yang di beri tugas untuk mendidik,melatih,dan membimbing para generasi muda untuk dimasa depan yang lebih berguna untuk bangsa dan negara. 
Betapa pentingnya peranan guru dalam sekolahan dan orang tua,terjalinnya sebuah hubungan yang harmonis antara guru,sekolah dan orang tua akan membuka peluang bagi guru dalam mengkoordinasi dan mengawasi dalam proses belajar mengajar di sekolah dan keterlibatan bersama untuk memajukan peserta didik.Guru diharapkan dapat melakukan yang terbaik sesuai dengan keinginan orang tua yaitu tercapainya sebuah mutu pendidikan yang berkualitas.

\section{Peragaan Dalam Pengajaran}

Peragaan dalam sebuah pengajaran sangatlah penting dalam pembelajaran karena dalam pembelajaran jika monoton akan membuat peserta didik merasa bosan,maka dari itu media alat peragaan sangatlah penting digunakan dalam proses belajar mengajar. Dalam mengajar kita harus pandai memilih alat peraga menurut William Burtonmemberikan petunjuk bahawa dalam memilih alat peraga yang akan di gunakan hendaknya kita memperhatikan hal-hal berikut:

1. Alat alat yang dipilih harus sesuai dengan kematangan dan pengalaman siswa serta perbedaan individual dalam kelompok

2. Alat yang dipilih harus tepat,memadai,dan mudah di gunakan 
3. Harus direncanakan dengan teliti dan diperiksa terlebih dahulu

4. Sesuai dengan batas kemampuan biaya

\title{
Kinerja Guru
}

\begin{abstract}
Kinerja seorang guru sangatlah di perlukan bagi terlaksananya sebuah pendidikan karena jika guru memiliki sebuah kinerja yang baik maka akan menghasilkan sesuatu yang baik pula,setiap guru di beri tugas untuk bekerja pada suatu organisasi dan diharapkan mampu menunjukkan kinerja yang dimiliki oleh setiap guru. Kinerja adalah tingkat keberhasilan seseorang atau kelompok orang dalam melaksanakan tugas dan tanggung jawab serta kemampuan untuk mencapai tujuan dan standar yang telah di tetapkan(Sulistyorini,2001).
\end{abstract}




\section{References}

Achmad Saifullah Syahid. (2015). Menjadi Guru, Sekadar Profesi Atau Panggilan Hati. Retrieved April 21, 2018, from https://www.kompasiana.com/achmadpon gsahidysaifullah/menjadi-guru-sekadarprofesi-atau-panggilanhati_57f53b55119373cc1e227ed3

Fidiana, W., Istiana, Z., Rosyidah, E., Purnomo, A. (2017). MINU Waru 2 Insan Berkilau Cahaya Manfaat. In Wirausaha Pendidikan Indonesia (Jilid 4). Sidoarjo: Unusida Press.

Maula, I., Asitah, N., Munjidah, A., Nahdiyah, K., Yuniarti, D., Sholichah, S. A., Purnomo, A., Anam, F., Rosyidah, E., Istiqomah, N., \& Qori'ah, S. (2018, May 25). Kontribusi Kreativitas Guru SD dalam Induksi Pembelajaran. http://doi.org/10.17605/OSF.IO/BS795

Nahdiyah, K., Amrina, S., Purnomo, A., \& Rosyidah, E. (2017). SD Taman Pendidikan Islam Porong Iman Kuat Bekal di Akhirat. In Wirausaha Pendidikan Indonesia (Jilid 2). Sidoarjo: Unusida Press.

Noviana, N. A. (2015). Peran Guru dalam 
Kegiatan Belajar-Mengajar. Retrieved April 21, 2018, from https://ilmupendidikan.net/profesi-

kependidikan/guru/peran-guru-dalamkegiatan-belajar-mengajar

Qori'ah, S., Sholikhah, S.A., Purnomo, A., \& Rosyidah, E. (2017). MI Progresif Bumi Sholawat dengan Kebenaran Semua Pasti Ada Jalan. In Wirausaha Pendidikan Indonesia (Jilid 3). Sidoarjo: Unusida Press.

Yuniarti, D., Kautsari, M.F., Sholichah, F., Purnomo, A., \& Rosyidah, E. (2017). SMP SMA Al-Amin Ponpes Bahrul Hidayah Serahkan pada Allah Ta'ala. In Wirausaha Pendidikan Indonesia (Jilid 1). Sidoarjo: Unusida Press. 